\title{
Deconstrucción de la interpretación \\ heideggeriana de la metáfora
}

\section{Hector Ariel Lugo}

Derrida promulga que la metáfora es un tema viejo, que siempre ha obsesionado a Occidente y que aún hoy día continúa poseyendo un interés inusitado, que procura renacer, replantearse de forma nueva. El sujeto-metáfora intenta retornar a pesar de los años y de lo desgastado que se lo encuentre. Aún, cuando la metáfora se halle en el atardecer de su vida, aunque se retire, se muestra como inagotable.

La metáfora es un "viejo tema" y por lo tanto está terminado, desgastado por el uso. La problemática generalmente planteada entorno de la metáfora es el uso ("valor de uso") que se le da y el desgaste que éste uso conlleva. Para Derrida, lo que se halla desgastado es el valor de uso y es esto, lo que ha suscitado la problemática (clásica) en torno a las metáforas muertas o metáforas vivas. Metáforas muertas serían las que han caído en desuso, por el contrario, metáforas vivas serían las que aún se mantienen en uso. Derrida haciendo referencia a esta distinción entre metáforas vivas y muertas que tradicionalmente se da, sostiene que las primeras, son las que tienen efectividad dentro de un discurso, es decir, que el autor ha querido que tengan cierto efecto metafórico; las segundas, son las que el autor no ha considerado que posean carga metafórica. La metaforización es el paso que se produce desde el sentido propio al figurado, desde lo sensible, pasando por la interiorización en la memoria y luego elevándose a lo inteligible-espiritual. Derrida, mantiene que ésta estrategia es propia del sistema hegeliano. ${ }^{1}$

La metáfora se traslada, nos traslada de un lugar a otro, se está en ella, es quien nos contiene. Es la metáfora un medio de transporte y uno se deja trasladar. Se habita en la metáfora. Pero para Derrida éstas expresiones no son metafóricas y a la vez no son propias, ni metafórica ni a-metafórica, sino que la metáfora posee el poder de intercambiar las

\footnotetext{
${ }^{1}$ Cfr. DERRIDA, Jacques. Márgenes de la filosofía. Trad. Carmen González Marín. Madrid, Cátedra, 1994. $2^{\mathrm{a}}$ ed. pp. 265-266. Una interesante crítica a la concepción de metáfora sostenida por Derrida puede encontrarse en Ricoeur. Cfr. RICOEUR, Paul. La metáfora viva. Trad. Graziella Baravalle. Buenos Aires, La aurora, 1977. p. 427 y 441
} 
funciones y los lugares. Cuando uno cree estar utilizando, sirviéndose de las metáforas, éstas son las que se sirven y trasladan a uno. Es la metáfora la que contiene y traslada, uno sólo se debe dejar llevar o se deja llevar sin saberlo, por la metáfora. "No estamos en la metáfora como un piloto en su navío." ${ }^{2}$ No se conduce la metáfora, sino que ella es la que lo conduce a uno.

Al procurar enunciar algo acerca de la metáfora, se debe hablar de manera metafórica. No se puede hablar sobre la metáfora en un sentido propio o conceptualizarla, sino que ella exige a uno a hablar more metaphorico. Rorty sostiene que la metáfora no es un relleno ni un ornamento sino que ella escapa al espacio lógico. La metáfora no posee un sentido literal y otro metafórico, ya que, esto significa que al aprender el lenguaje se puede aprender todas las posibilidades literales y metafóricas que figuran en él. ${ }^{3}$

Derrida y Rorty desde perspectivas distintas, coincide en que la metáfora no se puede entender como poseedora de un sentido literal y otro metafórico, ya que ello implicaría que se conociera los dos usos y la metáfora perdería todo su valor como modificadora de creencias para Rorty y para Derrida sería el haber podido apresarla en un concepto.

No se puede hablar de ella, sino que se debe hablar con ella. Es la metáfora quien concede los préstamos para que se hable de ella, por ello es ineludible "tratar con ella".

"No puedo tratar de ella sin tratar con ella, sin negociar con ella el préstamo que le pido para hablar de ella. No llego a producir un tratado de la metáfora que no haya sido tratado con la metáfora, la cual de pronto parece intratable." 4

Sólo se hablaría metafóricamente de la metáfora. La metáfora no permite que se la trate de otra manera. Así, conducidos por la metáfora, no se puede determinar dónde comienza o termina la misma, no se la puede controlar, ella es la que tiene el control, ella conduce y traslada a uno a su antojo. No se puede abandonar, dejar de hablar de la metáfora de forma metafórica. “... [I] ncluso si decidiese no hablar ya metafóricamente de la metáfora, no lo

\footnotetext{
${ }^{2}$ DERRIDA, Jacques. La Desconstrucción en las fronteras de la filosofía. La retirada de la metáfora. Trad. Patricio Peñalver Gómez. Barcelona, Paidós, 1989. p. 36

${ }^{3}$ Cfr. RORTY, Richard. Ensayos sobre Heidegger y otros pensadores contemporáneos. Escritos filosóficos 2. Trad. Jorge Vigil Rubio. Barcelona, Paidós, 1993. p. 30

${ }^{4}$ DERRIDA, Jacques. La Desconstrucción en las fronteras de la filosofia. La retirada de la metáfora. Óp. Cit. p. 36
} 
conseguiría, aquélla seguiría pasándome por alto para hacerme hablar, ser mi ventrílocuo, metaforizarme." 5

Derrida plantea que nada se da sin la metáfora, todo está transido de ella, cualquier enunciado tiene en su origen una producción metafórica. La metáfora misma se produce con metáforas. No hay metaforología posible que domine los lugares donde la metáfora se presenta.

Derrida en su escrito La mitología blanca, inicia preguntándose por la posibilidad de existencia de la metáfora en el texto considerado propio, "natural" del discurso de la filosofía. Sostiene que la metáfora y el texto filosófico son indisociables, y que la primera no puede dejarse de lado cuando se trata del texto filosófico. La filosofía no puede escamotear a la metáfora, es ésta la que sostiene el texto filosófico y no a la inversa.

“...la metáfora parece comprometer en su totalidad el uso de la lengua filosófica, nada menos que el uso de la lengua llamada natural en el discurso filosófico, incluso de la lengua natural como lengua filosófica."

Derrida invierte la concepción tradicional sobre la metáfora, ya que ésta no sería un simple ornamento exterior que se inserta en el texto filosófico y que en nada afecta a la esencia de éste, sino que la metáfora se halla en el centro del texto filosófico. La metáfora es propia de la filosofía.

Sostiene que la metáfora pasa por alto todo y prescinde de todo lo que pasa a través de ella o que no pasa sino por ella. La metáfora se pasaría por alto a ella misma, ya no se la podría identificar, ya no sería propiamente una metáfora. “...en un sentido insólito ella se pasa por alto a sí misma, es que ya no tiene nombre, sentido propio o literal..."7 Al pasarse por alto a sí misma, se eludiría de sí. No se podría sostener lo que es propio de ella. La metáfora no puede constreñirse a unos límites estrechos, ella los desborda y hace inútil toda restricción. Rorty refiriéndose a la metáfora como la posibilitadora del cambio de creencias, sostiene que no es posible distinguir el paso del sentido literal al metafórico y lo que en un primer

\footnotetext{
${ }^{5}$ Ibíd. p. 37

${ }^{6}$ DERRIDA, Jacques. Márgenes de la filosofía. Óp. Cit. p. 249

${ }^{7}$ DERRIDA, Jacques. La Desconstrucción en las fronteras de la filosofia. La retirada de la metáfora. Óp. Cit. p. 37 (Las negritas son mías)
} 
momento se consideró metafórico puede adquirir y adquiere el sentido un sentido literal y verdadero. ${ }^{8}$

La metáfora se retiraría en el momento de su mayor extensión, cuando los límites que la contenían se vuelven estériles. Su retirada dejaría una marca, una señal, en el trazo. Se retiraría dejando una marca para su retorno. La metáfora se retiraría en el momento de su mayor expansión, pero dejaría un rastro, en el texto, para poder siempre y constantemente retornar. “... [D] e una remanencia sobreabundante, de una repetición intrusiva, dejando siempre la señal de un trazo suplementario de un giro más, de un re-torno y de un re-trazo (re-trait) en el trazo (trait) que habrá dejado en el mismo texto."

Coincidiendo con Derrida, sostenemos que todos los esfuerzos de la tradición filosófica por conceptualizar a la metáfora han sido estériles y han sido realizados sobre la base de ignorar que en el origen estuvo la metáfora y que luego fue tomada por una verdad literal. Por otro lado, la metáfora es lo que molesta a la filosofía por no poder ser apresada en un concepto y paradójicamente, tener que recurrir constantemente a ella para hacer explícito ciertos significados literales. La metáfora es dejada al margen por no ser propiamente filosófica y ser solamente un suplemento, pero el suplemento se torna más importante que lo suplido al tener que recurrir a él, puesto que de otra manera jamás se recurría al mismo. La metáfora sería el sustituto insustituible al que siempre se debe recurrir, pero siempre se lo toma con cautela.

El creador de la deconstrucción privilegia el trato de la metáfora llevado a cabo por Martin Heidegger, éste solamente se refiere, explícitamente, a éste tema en dos textos y lo realiza de una forma reducida, sin detenerse demasiado en el tema. Pero Derrida, no se detiene en el tratamiento que en escasas ocasiones Heidegger da a la cuestión de la metáfora, sino que

\footnotetext{
${ }^{8}$ Cfr. RORTY, Richard. Ensayos sobre Heidegger y otros pensadores contemporáneos. Escritos filosóficos 2. Óp. Cit. pp. 30-31

9 DERRIDA, Jacques. La Desconstrucción en las fronteras de la filosofía. La retirada de la metáfora. Óp. Cit. p. 38
} 
hace referencia al "texto" heideggeriano, al trato que le da a la lengua. "... [D]el trazo como encentadura (entame) que rasga la lengua." 10

Heidegger, se refiere expresamente sobre la metáfora en dos textos, El principio de razón y Camino hacia el habla. Allí, critica el concepto de metáfora sostenido por la metafísica clásica. Derrida se cuestiona el por qué de recurrir a un texto que no aborde explícitamente el tema de la metáfora, ya que los dos textos mencionados no tienen por tema central a la metáfora, sino que sólo se ocupan de ella de manera aledaña y fugaz. “... ¿[P]or qué un texto que inscribe algo decisivo en cuanto a lo metafórico se habrá mantenido tan...retirado en cuanto a la metáfora como tal y bajo su nombre...de alguna manera propio o literal?..."11

Pero de la metáfora solamente se habla de forma metafórica y allí la cuestión, cómo poder determinar cuando se habla de forma propia de la metáfora, si siempre que se habla de ella se hace con la metáfora. ¿Cómo hablar propiamente de la metáfora, sí siempre que se habla de ella se habla metafóricamente? ¿Heidegger, habrá dado en el punto al tratar a la metáfora de forma tan reducida? ¿Habrá retirado a la metáfora para poder hablar de, sobre ella? ¿Habrá hablado con reserva de ella, sin dejar de hablar metafóricamente? Retirada de la metáfora, realizada por Heidegger que puede marcar el camino.

Heidegger centra su crítica en el paso de lo sensible a lo no-sensible (espiritual), en las pocas ocasiones que se refiere al tema y expone sus reservas con respecto al concepto de metáfora. Heidegger establece que la división de lo sensible / no-sensible es un rasgo fundamental, esencial, de la metafísica y que tal separación es imposible de realizar, siendo que no puede subsistir un ámbito sin el otro. La supuesta trasposición por medio de la metáfora de un ámbito al otro sería una ilusión de la metafísica de Occidente. Heidegger sostiene que no es posible discernir claramente donde acaba lo sensible y donde comienza lo no-sensible. La separación de lo sensible y lo no-sensible no tiene asidero y el transporte, la metáfora, se derrumba con ello. Así, la metáfora quedaría encerrada en el interior de la metafísica, sólo allí sería posible. Heidegger, sostiene; "Lo metafórico no

\footnotetext{
${ }^{10}$ Ibíd. p. 40

${ }^{11}$ Ibíd. p. 41 (Las negritas son mías)
} 
existe, sino en el interior de las fronteras de la metafísica."12 Pero Heidegger queda encerrado en la metafísica, al intentar dominar a la metáfora, es decir, al colocarse por fuera de la metafísica y de la metáfora para poder hablar de ellas. (Heidegger, a su vez criticaba la estrategia nietzscheana, de la inversión de valores, ya que la inversión de la metafísica lo situaría en una nueva postura metafísica.). Para Derrida, éste proyecto (meta-metafórico, meta-filosófico) es imposible de realizar, porque no se puede situar por fuera de la metáfora para dominarla.

En la concepción clásica, la metáfora es el paso de lo sensible a lo no-sensible. Así, lo nosensible adquiriría un sentido (significado), llamando a su vez sentido a aquello que se alejaría de los sentidos. El sentido sería la abstracción de los sentidos. Paradoja de la filosofía occidental.

Jacques Derrida analiza los textos donde Heidegger hace alusión a la metáfora y sostiene coincidiendo con Ricoeur ${ }^{13}$, que el poder de la metáfora atraviesa todo el texto heideggeriano y que este, poder es mucho más interesante que sus elaboraciones sobre la metáfora. La capacidad heideggeriana de metáfora, es más determinante que su acusación al concepto de metáfora que solamente se produciría en el interior de la metafísica. Heidegger busca apartarse de la concepción metafórica que podría producir su texto. Intenta retirar a la metáfora, al concepto metafisico de metáfora, de su texto, para que se lo entienda de forma propia.

Derrida expresa que el concepto de metáfora sólo es posible dentro de la metafísica como olvido, sustracción o retirada del ser. Sólo allí el concepto metafísico de metáfora es posible, en cuanto que la metafísica se presentaría como el olvido del ser. En la metafísica, a la que Heidegger dirige todos sus dardos, el ser se presentaría como oculto, estar-oculto (Verborgenheit), éste sería su modo (propio) de estar-presente, de ser (Sein). El ser al mostrarse esquivo, al hacerse presente ocultándose, se entrega al juego de la metáfora, queda prendado en un "desplazamiento metafórico-metonímico".

\footnotetext{
${ }^{12}$ HEIDEGGER, Martin. El principio de razón. Trad. Fr. Gallimard, p. 126. Citado por Derrida. Márgenes de la filosofia. Óp. Cit. p. 266

${ }^{13}$ Cf. RICOEUR, Paul. La metáfora viva. Óp. Cit. p. 422-424
} 
"El concepto llamado "metafísico" de la metáfora pertenecería a la metafisica en cuanto que ésta corresponde, en la epocalidad de sus épocas, a una epoché...a una retirada que deja en suspenso el ser...Al retirarse cuando se muestra o se determina como o bajo ese modo de ser...el ser se somete ya... a un desplazamiento metafóricometonímico."14

La metafísica no sería sino, en cuanto que en ella el ser se retira, una epoché del ser, donde el ser se haría presente mediante metáforas, "pasos trópicos"; y se buscarían respuestas mediante la conceptualización de aquello que no cae bajo conceptualidad alguna. Todos los conceptos de la metafísica y aún ella misma, tendrían un origen trópico. La metafísica se encontraría en relación trópica con respecto al ser. "Esta metafísica como trópica, y singularmente como desvio metafórico, correspondería a una retirada esencial del ser...el ser sólo podría nombrarse dentro de una separación metafórica-metonímica." ${ }^{15}$ Dentro de la metafísica el ser no se presenta sino solamente por medio de metáforas. La metafísica no podría hablar del ser sino metafóricamente y por ello, recurre a una "gran metáfora del ser o de la verdad del ser”, para aunar las semejanzas. La metafísica hablaría con la metáfora, del ser. La concentración de las diferencias metonímicas se esfuman en la semejanza de la "gran metáfora", ésta sería el medio por el cual la metafísica se expresaría, "sería la lengua de la metafísica."16

Sostiene que la metáfora se expresa en el ámbito del ente. Todo lo que sea ente se transporta a través de la metáfora o es atravesado por ésta. Pero el ser no es un ente y por lo tanto no puede ser expresado por la metáfora, ya que en la metafísica de la presencia el ser se halla retirado. La metafísica utiliza las metáforas para describir relaciones entre entes y por lo tanto, no se puede sostener que del ser, ella habla de forma (propiamente) metafórica. Del ser no es posible hablar de forma metafórica, ni tampoco de manera propia. El ser estaría en un punto ciego, donde no se lo podría mostrar o hablar de él a no ser de una manera que lindara entre lo literal y lo metafórico. Metáfora y ser, entre éstos dos se produce el juego de las retiradas, de lo metafórico y de lo propio.

\footnotetext{
${ }^{14}$ DERRIDA, Jacques. La Desconstrucción en las fronteras de la filosofia. La retirada de la metáfora. Op. Cit. p. 56

${ }^{15}$ Ibíd. p. 57

${ }^{16}$ Ibíd.
} 
"Del ser se hablará siempre quasi metafóricamente, según una metáfora de metáfora, con la sobrecarga de un trazo suplementario, de un re-trazo. Un pliegue suplementario de la metáfora articula esa retirada, al repetir desplazándola la metáfora intrametafísica, aquella misma que se habrá hecho posible por la retirada del ser." 17

Así, sostiene que para Heidegger el olvido, la retirada del ser es una característica propiamente metafísica, de "la" metafísica. Por lo tanto, el concepto metafísico de metáfora se correspondería con la "retirada del ser". La metafísica para referirse al ser, para hablar de él, lo hace en el límite de lo propio y lo metafórico, de forma quasi metafórica, ésta forma de expresarse posibilitaría y contendría al concepto de metáfora que se produciría dentro de la metafísica. Metáfora de metáfora.

Doble retirada, del ser y de la metáfora. Es posible eludir a la metafísica por medio de la retirada de la metáfora en tanto concepto de la metafísica. Retirada del ser en la metafísica y retirada de la metáfora como concepto metafísico. Retiro de la retirada del ser. Alejamiento de la metafísica por medio de la retirada de la metáfora. Vuelta a lo que la metafísica había dejado de lado.

"El discurso metafísico no puede ser desbordado, en cuanto que corresponde a una retirada del ser, a menos que lo sea conforme a una retirada de la metáfora en cuanto que concepto metafisico, conforme a una retirada de lo metafísico, una retirada de la retirada del ser." 18

La retirada de la metáfora ha dejado el lugar libre momentáneamente, ya que volverá continuamente. No se retira y en su sitio es posible ubicar un discurso de lo propio, sino que se re-pliega para re-tornar una y otra vez. Retirada de la metáfora y lugar a la generalización de la misma. Ausencia, retiro de la metáfora y paradójicamente, metáforas por todos lados. Ninguna retórica podrá ya, dominar a la metáfora. "La retirada de la metáfora da lugar a una generalización abismal de lo metafórico...que ensancha los bordes o que más bien los invagina." 19

\footnotetext{
${ }^{17}$ Ibíd. pp. 57-58

${ }^{18}$ Ibíd. p. 58 (Sólo resalto la última frase)

${ }^{19}$ Ibíd.
} 
Para Derrida, al retirarse el ser posibilita la metafísica que se convierte en una ontoteología generándose en su interior el concepto metafísico de metáfora, que se expresa de manera quasi metafórica. "La retirada del ser, su estar retirado, da lugar a la metafísica como ontoteología que produce el concepto de metáfora, que se produce y que se denomina de manera quasi metafórica." ${ }^{20}$ Aquí mismo, surge la posibilidad de pensar la retirada del ser por medio de la retirada de la metáfora, pero éste ocultamiento de la metáfora hace que se proliferen las metáforas.

"Para pensar el ser en su retirada, habría en consecuencia que dejar que se produjera o que se redujera una retirada de la metáfora que, sin embargo, al no dejar sitio a nada que sea opuesto, oponible a lo metafórico, extenderá sin límites y recargará con plusvalía suplementaria todo trazo metafórico." ${ }^{21}$

Retirada de la metáfora y sitio que queda en suspenso, inhabitado hasta su regreso.

El concepto de metáfora y la retirada de la misma, es producido por la "retirada del ser", y ésta expresión no es posible tomarla como propiamente metafórica. La palabra retirada, utilizada por Derrida, se encontraría en el camino intermedio entre lo literal y lo metafórico, no sería ni propiamente literal ni metafórica, sino que sería una quasi metáfora.

La metáfora es lo que disloca el sentido y sume en la inseguridad del sin-sentido a la "metafísica de la presencia", ya que ella deposita su creencia en que la voz hace trasparente el pensamiento y que sólo estando en presencia se puede expresar el pensamiento a través de la voz, de forma plena ("Logofonocentrismo"). La metáfora no se muestra de forma plena, sino que siempre insinúa, se hace presente a través de rodeos. Se presenta ausentándose. La "metafísica de la presencia" considera que es por el concepto que se debe guiar, pero para Derrida, no se percata que estos no son sino catacresis. ${ }^{22}$

\footnotetext{
${ }^{20}$ Ibíd. p. 59

${ }^{21}$ Ibíd.

${ }^{22}$ Con respecto a la relación de la metáfora y la escritura en la "metafísica de la presencia": “...tout ce qui fonctionne comme métaphore dans ces discours confirme le privilège du logos et fonde le sens "propre» donné alors à l'écriture : signe signifiant un signifiant signifiant lui-même une vérité éternelle, éternellement pensée et dite dans la proximité d'un logos présent. Le paradoxe auquel il faut se rendre attentif est alors le suivant : l'écriture naturelle et universelle, l'écriture intelligible et intemporelle est ainsi nommée par métaphore. L'écriture sensible, finie, etc., est designee comme écriture au sens propre; elle est alors pensée du côté de la culture, de la technique et de l'artifice : procédé humain, ruse d'un être incarné par accident ou d'une créature finie. Bien entendu, cette métaphore reste énigmatique et renvoie à un sens «propre» de
} 
Para Derrida, las frases "retirada del ser" y "retirada de la metáfora", se referirían al vehículo, al transporte (retirada) y no tanto al tema que pretenden tratar. La frase "retiradade" no puede tomarse en un sentido estrictamente metafórico, de hacerlo se estaría expresando algo novedoso del transporte y no de lo transportado. Se trataría de la retirada y no tanto del ser o la metáfora.

“....si se pretendiese que retirada-de se entendiera como una metáfora, se trataría de una metáfora curiosa, trastornadora, se diría casi catastrófica, catastrópica: tendría como objetivo enunciar algo nuevo, todavía inaudito, acerca del vehículo y no acerca del aparente tema del tropo." 23

Concluye que el pensamiento que se tenía de la metáfora en la concepción clásica ha perdido vigencia y ya no se sostiene, porque la metafísica se basaba en un conocimiento familiar y a través de la metáfora, mediante la analogía, arribar a un conocimiento nuevo. Pero para Derrida, el pensamiento de la metáfora sólo es posible por medio de pensar la “diferencia óntico-ontológica" y que ésta es posible pensarla mediante la acción de la retirada. Se invierte la concepción tradicional de la metáfora, ya no se posee el conocimiento cierto que produciría el concepto metafísico de la metáfora. La metáfora se muestra incontenible en cualquier concepto metafísico que quiere contenerla. Lo catastrófico es que no se piensa al ser o la metáfora desde un conocimiento de la metáfora retirada, sino que es necesario pensar primero la diferencia óntico-ontológica. Lo metafórico no se puede conceptuar.

Se refiere al modo de expresarse que tiene Heidegger, que cuando pareciera soltar una frase que se la interpretaría de forma metafórica (desde la concepción metafísica de metáfora), sostiene que se la debe comprender tal cual se muestra, que lo que dice no es una metáfora. De esta forma Heidegger introduce la duda en la concepción metafísica de metáfora y lo que tradicionalmente se tiene por supuesto de lo que bajo ese concepto debe figurar. Heidegger cuestiona lo que se entiende por metáfora y hace que surjan preguntas; ¿qué es

l'écriture comme première métaphore. Ce sens «propre» est encore impensé par les tenants de ce discours. Il ne s'agirait donc pas d'inverser le sens propre et le sens figuré mais de déterminer le sens "propre» de l'écriture comme la métaphoricité elle-même." DERRIDA, Jacques. De la grammatologie. Paris, Les Éditions de Minuit, 1967. p. 27

${ }^{23}$ DERRIDA, Jacques. La Desconstrucción en las fronteras de la filosofía. La retirada de la metáfora. Óp. Cit. p. 60 
una metáfora? ¿qué se entiende cuando hablamos de ella? ¿qué es lo metafórico y qué lo propio? ¿dónde empieza lo metafórico y dónde lo propio? Cuestiones de difícil solución, pero que se dirigen a demoler la metafísica, la jerarquía impuesta por ésta para diferenciar de forma tajante y sin discusión entre lo que se entiende por metafórico y propio. Para Heidegger, el concepto metafísico de metáfora no posee sustento y por lo tanto, la metafísica misma quedaría destruida, ya que la delimitación de lo metafórico y lo literal no se sostendría. No se podría discernir cuando se habla propia o metafóricamente. Rorty analizando la interpretación heideggeriana sostiene que la tarea de la filosofía por excelencia es alcanzar la fuerza de las metáforas antes de que ellas se hayan transformado en verdades literales, antes de que se hayan hecho familiares por el uso y demostrar su contingencia histórica. Para alcanzar el lenguaje prístino en que el Dasein se expresaba. ${ }^{24}$

Derrida alude a esta forma paradójica (que cuando sus frases se prestan más a una interpretación metafórica, él sostiene que no lo son) de referirse a la metáfora que posee Heidegger y que en varios textos se dirige de esa manera. Un ejemplo de ello es el texto Carta sobre el humanismo, allí se sitúa su célebre frase sobre la "casa del ser"25, que Derrida analiza. Para Heidegger, ésta frase no se la debe tomar de forma metafórica, tampoco sostiene que la palabra casa, familiar a todos, funcione como metáfora y por medio de la analogía se llegase a comprender lo que el ser es, sino que pensando adecuadamente el ser, se podrá llegar a comprender lo que es la casa y todas las demás cosas. Es necesario pensar el ser (en su retirada), para poder pensar todo lo demás. El ser al retirarse posibilitaría pensar la casa. "Cabría la tentación de formalizar esa inversión retórica en la que, en el tropo "casa del ser”, el ser nos dice más, o nos promete más sobre la casa que la casa sobre el ser." ${ }^{26}$ Pero Derrida, no se deja tentar y sostiene que el ser no

\footnotetext{
${ }^{24}$ Cfr. RORTY, Richard. Ensayos sobre Heidegger y otros pensadores contemporáneos. Escritos filosóficos 2. Óp. Cit. p. 34. Rorty concuerda con la crítica derridiana al cometido de Heidegger, de retornar al lenguaje primigenio en el que se expresaba el Dasein antes que las metáforas se convirtieran en verdades literales y sostiene que es una "nostalgia carente de objeto". p. 150

25 "El pensar lleva a cabo la relación del ser con la esencia del hombre...Este ofrecer consiste en que en el pensar el ser llega al lenguaje. El lenguaje es la casa del ser. En su morada habita el hombre." HEIDEGGER, Martin. "Carta sobre el humanismo". En: Realidad. Revista de Ideas. Trad. A. Wagner de Reina. Buenos Aires. Año II, Vol. III, N 7, enero-febrero 1948. pp. 1-2. (Traducción modificada por mi)

${ }^{26}$ DERRIDA, Jacques. La Desconstrucción en las fronteras de la filosofía. La retirada de la metáfora. Op. Cit. p. 62
} 
se transformaría en algo familiar, bien conocido, que permitiría pensar el ser de la casa, el ser no es lo propio de la casa. Así, no se estaría en la concepción clásica de metáfora, ni tampoco en el intercambio de sitios (casa por ser y viceversa) de lo que se considera usualmente una metáfora.

El ser se podrá pensar únicamente en y desde el lenguaje, die Sprache. Sólo allí es posible que el ser sea percibido, que se muestre más próximo. Die Sprache es la morada del ser, es donde el hombre, guardando la verdad del ser, eksiste.

Derrida considera que el accionar de Heidegger no es posible tomarlo como meramente metafórico, sino que hace alusión al lenguaje y a la lengua como constituyentes de lo metafórico. Así mismo, alude el pensar el ser desde la diferencia ontológica, ésta posibilita la retirada del ser, la aparición de la metáfora y la retirada, a su vez, de ésta última. No se puede tomar a los términos de las frases de Heidegger de forma propia o metafórica, quedarían en el ámbito de la quasi metáfora. ${ }^{27}$

“Al enunciar no literalmente la condición de la metaforicidad, libera tanto la extensión ilimitada como la retirada de aquélla....Siempre una metáfora más en el momento en que la metáfora se retira ensanchando sus límites."28

La metáfora es ilimitada siempre; es posible siempre una metáfora de metáfora y siempre será una metáfora más. No hay metarretórica, ni metafísica que pueda contener ni encerrar a la metáfora.

Sostenemos que la filosofía ha intentado siempre mantenerse en la seguridad que le brindaba la conceptualización y a su vez, ella implica la verdad. Todo lo que no sea comprensible y no pueda encasillarse es desestimado, pero es justamente el encerrarse en esas estructuras dicotómicas lo que impide la comprensión de algo que escape a sus márgenes estrechos. La metáfora genera inseguridad y por lo tanto es peligrosa por no saber bien que es, ya que insinúa pero no se muestra plenamente.

\footnotetext{
${ }^{27}$ Cfr. Ibíd. pp. 63-64

${ }^{28}$ Ibíd. p. 64
} 
Desde nuestra perspectiva, centrarse en eso sin-sitio que escapa a la conceptualización clásica es lo que posibilita la deconstrucción de las pretéritas estructuras para incorporar cuestiones que habían sido excluidas de sus intereses.

Jacques Derrida, plantea la question de entender a la expresión retirada de la metáfora como metafórica, si no habría una metáfora última que sustentara a todo el recorrido de la diferencia ontológica, la retirada del ser y de la metáfora. “ ¿No habría en última instancia, detrás de todo este discurso, sosteniéndolo más o menos discretamente, retiradamente, una metáfora de la retirada que autorizaría a hablar de la diferencia ontológica y, a partir de ésta, de la retirada de la metáfora?"29

La respuesta de Derrida a ésta pregunta es que lo metafórico no se puede limitar y se confirmaría lo que Heidegger criticaba al proyecto metafísico como construcción de una metalingüística que pudiera conceptuar, absorber y manejar a la metáfora.

En una estrategia deconstructiva, Derrida aborda la relación de "vecindad" entre pensamiento y poesía que sostiene Heidegger. Derrida, mantiene que adoptar a la relación de "vecindad" (proximidad) entre el pensamiento y la poesía, como una metáfora y suponiendo que se sabe lo qué es, es retornar al punto de vista metafísico. Para Derrida, es alejándose de ésta concepción (la seguridad de lo que la metáfora es) como realmente es posible arribar a una óptica novedosa y pensar auténticamente la "proximidad de la vecindad". Es pensando y replanteando el "concepto" metafísico de metáfora, como realmente se podrá obtener una nueva visión y ésta permitirá el acceso a la metáfora. Pero, la vecindad no es desconocida antes de éste acceso, sino que es familiar y hay que retornar “allí donde estamos sin estar propiamente". La vecindad implica que alguien se encuentra próximo y uno se encuentra próximo de aquel. Ésta proximidad funciona como un imán que atrae a ambas partes hacia la relación de vecindad. La vecindad entre pensamiento y poesía no es propiamente metafórica, no se la podría entender así propiamente, pero ésta vecindad es la que posibilita la introducción a la proximidad de la vecindad. Y la indeterminación entre lo metafórico y lo literal, de la vecindad, lleva a un replanteamiento de lo que se comprende bajo el nombre de metáfora.

${ }^{29}$ Ibíd. p. 65 
Entre pensamiento y poesía, existe el "trazo" que los aproxima, a la vez que los diferencia irremediablemente, "que avecina". El trazo que los diferencia y que a la vez tiende a unirlos, los limita a uno y a otro, los recorta, "se recortan" recíprocamente.

" $Y$ este trazo (Riss) es un corte que se hacen, en alguna parte en el infinito, los dos vecinos, Denken und Dichten. En la entalladura de ese corte, se abren, podría decirse, el uno al otro, se abren desde su diferencia e incluso...se recortan en su trazo y en consecuencia en su retrazo respectivo." 30

El trazo que los vincula y los "recorta", no es de uno o de otro, sino que no les pertenece, tampoco es un concepto universal o una metáfora. El trazo se halla en el origen y por lo tanto es anterior al pensamiento y a la poesía. El trazo es el lugar, ilocalizable, de donde, Denken und Dichten, tienen su origen y es en donde se unen ambos. Es una zona liberada donde ninguno de los dos logra conseguir una hegemonía. El trazo hace posible que en la lengua se pueda nombrar, sin embargo, a él mismo es imposible nombrarlo, ya sea de forma metafórica o literal. "No tiene nada que se le aproxime en cuanto tal.",31

Denken y Dichten se hallan perfectamente diferenciados, pero no apartados sin relación alguna, sino que entre ellos existe una irreprimible tendencia, atracción, tracción entre sí. El trazo marca ésta relación. El trazo de la "encentadura" (Aufriss, entame) ${ }^{32}$ que abre paso. Aufriss se traduce por entame, "encentadura" y ésta se encenta a sí misma. Aufriss, es utilizada por Heidegger para nombrar lo que hasta ese momento permanecía oculto, ella misma se nombra. "...LL]lamar Aufriss a lo que de una cierta manera se encontraba todavía innombrado o ignorado bajo ese nombre, es ya en sí misma una encentadura; aquélla no puede hacer otra cosa que nombrarse, autonombrarse, y encentarse en su propia escritura." 33 La unidad de Sprache que permanecía, para Heidegger, oculta, innombrada, para el discurso de la metafísica (porque ésta se centraba en un punto de vista descuidando otros), "se llama" Aufriss. Para Heidegger, el Aufriss es la esencia misma, la unidad, lo propio de Sprache. "La buscada unidad de la esencia de la Sprache se llama la

\footnotetext{
${ }^{30}$ Ibíd. p. 67

${ }^{31}$ Ibíd.

${ }^{32}$ Derrida, propone la traducción de la palabra Aufriss, utilizada por Heidegger y que hace referencia a una decisión que no es voluntaria de ninguna de las dos partes, por la palabra entame, y que Patricio Peñalver traduce por encentadura.

${ }^{33}$ Ibíd.
} 
encentadura" ${ }^{34}$ Aufriss, no es meramente un trazo, sino que contiene a todo trazo, pero permaneciendo oculto, nunca se devela o bien, se devela ocultándose. Es lo que une, separa y abre de Sprache. El velamiento de la encentadura se da en tanto no se dirija propiamente a la esencia de Sprache, al Aufriss. "El trazo de la encentadura está pues velado, retirado, pero es también el trazo que reúne y separa a la vez el velamiento y el desvelamiento, la retirada y la retirada de la retirada." 35

El trazo se recorta a sí mismo, en éste último se inscribe escondiéndose, retirándose. "En el recorte, el trazo se señala a sí mismo al retirarse, llega hasta borrarse en otro, a reinscribirse en éste paralelamente, en consecuencia, heterológicamente, $y$ alegóricamente. El trazo es retirada (Le trait est retrait)." ${ }^{36}$ El trazo aparece siempre retirándose. Trata consigo mismo, se da a la vez que se quita a sí.

Marca, trazo que queda en ellas, marca su vecindad, pero que no las hiere sino que las sella, las encentan.

“...esa entalladura (Schnitt), no se la hacen a sí mismas, sino que recortan sin tocarse, sin afectarse, sin herirse. Solamente se encentan y son cortadas (geschnitten) en la encentadura (Aufriss) de su vecindad, de su esencia que avecina (nachbarlichen Wesens).

El lugar de la vecindad, de la encentadura y la aproximación es el Ereignis, allí el pensamiento y la poesía encuentran o van hacia su esencia propia. Pero el Ereignis no antecede a ambos, sino que él es con ellos, no siendo nada antes. "El trazo de la encentadura, pues, señala el Ereignis como apropiación, acontecimiento de apropiación. ${ }^{38}$ El trazo se borra en su propia encentadura, el trazo aparece para retirarse. El trazo se inscribe borrándose.

\footnotetext{
${ }^{34}$ HEIDEGGER, Martin. De camino al habla. Trad. Yves Zimmermann. Barcelona, Serbal, 1990. Citado por Derrida. Ibíd. pp. 70-71

${ }^{35}$ DERRIDA, Jacques. La Desconstrucción en las fronteras de la filosofía. La retirada de la metáfora. Op. Cit. p. 71

${ }^{36}$ Ibíd. pp. 71-72

${ }^{37}$ Ibíd. pp. 68-69

${ }^{38}$ Ibíd. p. 69
} 
El trazo no es nada antes del advenimiento del Denken y Dichten, de la encentadura de ambos, pero tampoco es derivado. Surge en el momento mismo de la apariencia de los dos que corta, que encenta, pero paradójicamente, al mimo tiempo no es meramente secundario, no es absolutamente dependiente ni tampoco independiente. "El re-del retrazo no es un accidente que sobreviene al trazo. Este se destaca permitiendo a toda propiedad destacarse, como se dice de una figura sobre un fondo. Pero no se destaca ni antes ni después de la encentadura que permite destacarse..."39 Para Derrida, el destacarse del trazo, del "re-trazo" no se puede someter a las viejas oposiciones dicotómicas que son tan caras a la metafísica. Éstas oposiciones del discurso metafísico tendrían su punto de partida, en la "retirada del trazo". Todas las oposiciones de que se sirve la metafísica. Derrida, mantiene que existe una relación entre el re- de la retirada y el Enteignen, que ambos dejan su marca en el Ereignis. “... [L] a relación entre el re-de la retirada...y el Ereignen del es gibt...en ese trazo precisamente en el que el movimiento del Enteignen (des-apropiación, retirada de propiedad) viene a cavar todo Ereignis. ${ }^{40}$

Derrida busca captar el cruce entre Reissen (desgarrarse, disputar una cosa, apoderarse de algo) y Ziehen (tirar, mudarse, estirarse), el punto de unión entre ambos, de una lengua en la otra. (¿Cómo trasladar una palabra de una lengua a otra? ¿Cómo saber si ese traspaso ha sido exitoso? ¿Cómo lograr que una palabra logre el mismo efecto en una lengua que en otra? ¿Cómo al traducir, evitar el abuso? “...una "buena” traducción debe ser siempre abusiva" $\left.^{, 11}\right)$.

Pero para que el traslado de una lengua a otra se produzca, para que se pueda captar, "capturar" ese momento preciso de cruzamiento entre las lenguas, para "encentarlo", es necesario saber que el "trato" (entre las lenguas) se halla en acción, "actúa”, en la lengua del otro.

El entrecruzamiento de Reissen y Ziehen es una atracción irresistible y recíproca, que se halla marcado por el trazo (Riss), que tiende a la unión de ambos en Aufriss. "El trazo

\footnotetext{
${ }^{39}$ Ibíd.

${ }^{40}$ Ibíd. p. 70

${ }^{41}$ Ibíd. p. 59
} 
(Riss) no hace hendirse a los opuestos, atrae la adversidad hacia la unidad de un contorno (Umriss), de un marco, de un armazón (en el sentido corriente)." 42

El Riss realiza una apertura y posibilita pensar sin límites lo que antes se hallaba limitado bajo el discurso metafísico. Pero, el trazo no es un ente, no es nada, no se lo puede reducir a uno de los lados de las categorías binarias que son típicas de la metafísica occidental, la encentadura se halla precisamente en el medio y es por ello que es impensable para la tradición metafísica. La encentadura del Aufriss es el punto de separación, a la vez que de unión. "Todas las oposiciones de valor tienen su posibilidad en la diferencia, en el entre de su separación que concilia tanto como desmarca." $"$ No se puede abordar al "entre" desde los conceptos de la metafísica, para hablar de él es necesario un replanteamiento de toda la tradición metafísica. No se puede tratar a ese "entre", a la "encentadura", al "Aufriss", de forma metafórica, ni se puede construir una metarretórica para abordarlos.

La retirada posibilita que se encuentre el trazo, sólo con aquélla se hace posible pensar el trazo, pensar una forma diferente de enfrentarse con los discursos metafísicos. En el trazo, en la retirada, es factible hallar el punto de separación y de unión, de "diferencialidad".

La retórica no podrá abordarse a sí misma, no se podrá elaborar una metarretórica que trate, que abarque completamente al trazo. "La retórica no podrá entonces enunciarse a sí misma y su posibilidad, más que desplazándose al trazo suplementario de una retórica de la retórica..."

La retirada no se la debe concebir como metafórica, ni como literal, sino que es ambas cosas a la vez y no es nada. “"Retrait” no es más propio, ni literal, que figurado. No se confunde ya con las palabras que él hace posibles, en su delimitación o recorte...como tampoco es extraño a las palabras como una cosa o un referente." 45 La retirada hace posible el surgimiento de palabras, pero no es ninguna de ellas. La retirada no es un objeto, tampoco un sentido, ni una cosa oculta todopoderosa. La retirada se retira a sí misma y posibilita pensar la diferencia ontológica. El "trazo suplementario" siempre presente para que sea posible la retirada de la retirada, la metáfora de la metáfora. Se producirían

\footnotetext{
42 Ibíd. p. 73

${ }^{43}$ Ibíd. pp. 73-74 (Las negritas son mías)

${ }^{44}$ Ibíd. p. 74 (Las negritas son mías)

${ }^{45}$ Ibíd.
} 
"retiradas" (en plural) serían la unión y la separación que se darían en la retirada de la retirada. Siempre un trazo suplementario más a una retirada.

"Se retira del ser del ente como tal y del lenguaje, sin que esté, ni sea dicho, en otra parte; encenta la diferencia ontológica misma. Se retira pero la ipseidad del se mediante la que se relacionaría consigo mismo con un trazo no la precede y supone y a un trazo suplementario para trazarse, firmar, retirar, trazar a su vez."46

Se produce una retirada de la retirada de la metáfora, donde nada puede pasar a la metáfora por alto y ella se pasa por alto a sí. No hay elaboración de repuesta con respecto a la metáfora que pueda encerrarla, que puede abarcarla en su totalidad. Derrida, concluye su discurso y sostiene que nada puede pasar por alto a la metáfora. "Nada, ninguna respuesta, sino que la retirada de la metáfora pasa a ésta por alto, y a sí misma.",47

\section{Algunas reflexiones finales}

Sostenemos con Derrida, que coincide con Heidegger, que la "metafísica de la presencia" halla su seguridad en la conceptualización y que la metáfora sería dejada de lado por quebrantar el sentido literal que intenta expresarse en el lenguaje. Lo que no halla categoría a la cual adaptarse es destinado a las sombras, es desechado. La metáfora genera inseguridad por sólo insinuarse. Solamente se recurre a la metáfora cuando mediante los conceptos no se puede hacer explicito el sentido.

Pero la metáfora no sería un mero ornamento o la que expresa lo inexpresable por el concepto, llenando un vacío, sino que es en la metaforicidad en que se construye el concepto, sin haberse percatado de ello. Así entendida la metáfora es la posibilitadora de quebrantar las estructuras en las que se sustenta la "metafísica de la presencia", lleva al extremo para comprobar que los antiguos márgenes de los conceptos tradicionales quedan

\footnotetext{
${ }^{46}$ Ibíd. pp. 74-75

${ }^{47}$ Ibíd. p. 75
} 
estrechos y son insuficientes para contener a la metáfora, ya que ella se expresa metafóricamente.

Se puede apreciar el sentido político de la deconstrucción, centrándose en la metáfora, ya que arremete contra la tradición filosófica y cuestiona los supuestos de la misma. Desde este punto de vista, sostenemos que el poder de la deconstrucción reside en pensar esos márgenes para demostrar que ciertas cuestiones han sido excluidas, conciente $o$ inconcientemente, de la preocupación de la filosofía occidental.

La "metafísica de la presencia" considera que las metáforas se derivan de los conceptos. Siendo que los conceptos son metáfora olvidadas, como lo sostenía Nietzsche, y que se los toma en sentido literal. Cuando las metáforas son olvidadas se convierten en conceptos.

Las críticas de Heidegger y Derrida, nos posibilitan un replanteamiento de esa imposible pretensión de la filosofía clásica de moverse pura y exclusivamente en el ámbito de la conceptualización. Estas críticas amplían nuestra perspectiva y nos permiten pensar lo hasta ahora no-pensado.

Bibliografía:

DERRIDA, Jacques. De la grammatologie. Paris, Les Éditions de Minuit, 1967. 


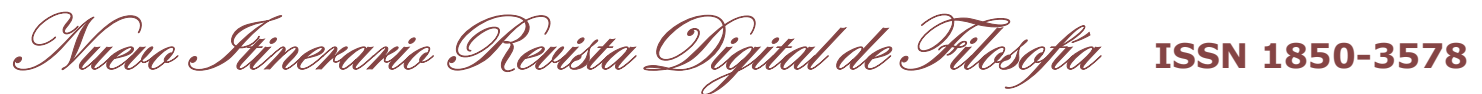

La Desconstrucción en las fronteras de la filosofía. La retirada de la metáfora. Trad. Patricio Peñalver Gómez. Barcelona, Paidós, 1989.

Márgenes de la filosofía. Trad. Carmen González Marín. Madrid, Cátedra, 1994. $2^{\mathrm{a}}$ ed.

HEIDEGGER, Martin. De camino al habla. Trad. Yves Zimmermann. Barcelona, Serbal, 1990.

HEIDEGGER, Martin. "Carta sobre el humanismo”. En: Realidad. Revista de Ideas. Trad. A. Wagner de Reina. Buenos Aires. Año II, Vol. III, № 7, enero-febrero 1948.

RICOEUR, Paul. La metáfora viva. Trad. Graziella Baravalle. Buenos Aires, La aurora, 1977.

RORTY, Richard. Ensayos sobre Heidegger y otros pensadores contemporáneos. Escritos filosóficos 2. Trad. Jorge Vigil Rubio. Barcelona, Paidós, 1993. 